\title{
Insurgency Decision-making under Conditions of Risk
}

\author{
Albert Wesley Harris ${ }^{1}$ \\ ${ }^{1}$ Department of Politics, Humboldt State University, Arcata, USA \\ Correspondence: Albert Wesley Harris, Department of Politics, Humboldt State University, Arcata. CA. 95521, \\ USA. Tel: 1-707-826-3131. E-mail: awh2@humboldt.edu
}

$\begin{array}{lc}\text { Received: April 24, } 2012 & \text { Accepted: June 25, } 2012 \quad \text { Online Published: July 16, } 2012 \\ \text { doi:10.5539/ijps.v4n3p43 } & \text { URL: http://dx.doi.org/10.5539/ijps.v4n3p43 }\end{array}$

\begin{abstract}
Utilizing prospect theory, the paper contends that two insurgencies, the Liberation Tigers of Tamil Eelam and the Chechen resistance, decided to mount a stand at Kilinochchi in Sri Lanka, and Grozny in Chechnya, because they preferred to accept the risk of losing the battles, incurring greater casualties (rather than choosing to abandon the two sites respectively) and potentially losing the war, on the chance they could win the respective battles and turn the tide of the civil war generally. In terms of prospect theory, the two insurgencies underweighted the high probability of losing the respective battles, and demonstrated the prevalence of risk aversion in choices between probable gains and sure things, and the prevalence of risk seeking in choices between probable and sure losses.
\end{abstract}

Keywords: insurgency, loss-aversion, risk-seeking, endowment, casualties

\section{Introduction}

In 2009 the Liberation Tigers of Tamil Eelam (LTTE) became embroiled in merciless combat with the Sri Lankan Army (SLA) at a site labeled Kilinochchi, located in the northern portion of the island. The LTTE had been seriously damaged in earlier combat, but chose to stand and fight at Kilinochchi (U.N. Secretary-General, 2011, p. 23; ICG, 2008, p. 5; Hariharan, 2008). In 1999 the Chechen resistance in Chechnya, Russia, became engaged in brutal combat with the Russian army at Grozny, the capital of Chechnya. The Chechen resistance had been significantly depleted by earlier combat with the Russian forces, but chose to stand and fight at Grozny (Oliker, 2001, pp. 41-42; Gordon, 1999, p. 10; New York Times, 1999).

\subsection{Loss Aversion in Civil War}

These respective decisions by the two insurgencies may be best explained by applying prospect theory to these separate but analogous events (Khaneman \& Tversky, 1979; Tversky \& Kahneman, 1992). My contention is that both insurgencies decided to make a stand at the two sites because they preferred to accept the risk of losing the battles, incurring greater casualties (rather than choosing to abandon the two sites) and potentially losing the war, on the chance they could win the battle and turn the tide of the civil war generally. But this latter potential outcome (winning the battle and thus turning the tide of the war) was significantly less likely than an outcome which would have entailed had the insurgencies chosen to retreat, which would have meant losing territory for certain, but would have incurred significantly fewer casualties, and would have held open the option (or increased the likelihood) of surviving to fight another day. In terms of prospect theory the two insurgencies "underweighted" the high probability of losing the respective battles, and demonstrated "the prevalence of risk aversion in choices between probable gains and sure things, and ... the prevalence of risk seeking in choices between probable and sure losses" (Tversky \& Khaneman, 1992, p. 316).

\subsection{Risk Acceptance}

The two insurgencies chose to "stand their ground" even though the odds of success (winning the battles and ultimately the civil wars) were small, and the costs of losing the battles could mean increasing the likelihood of losing the wars. But the potential gains from winning the two battles were large; potentially turning the tides of both wars. The two insurgent organizations could have chosen to retreat, gaining time to regroup, and thus possibly winning the war over a longer term. But retreating would mean giving up ground to the adversary, a certain but smaller loss (especially in terms of casualties), even if that ground could conceivably be regained at a 
later time. The two respective decisions, by the Chechen resistance and the LTTE, to mount metropolitan defenses would have been anticipated by prospect theory (Kahneman \&Tversky, 1983, p. 348). Prospect theory argues that "actors should be much more willing to run risks when they believe that failing to do so will result in certain losses" (emphasis added) (Jervis, 1992, p. 195).

\subsection{Endowment Affect}

There is strong reason to believe that the respective insurgencies viewed the prospects of abandoning Grozny to the Russians in 1999, and surrendering Kilinochchi to the SLA in 2009, as prospective losses, not simply reductions in past gains. In this paper I hold that, similar to individuals, groups can be loss-averse. "An immediate consequence of loss-aversion is that the loss of utility associated with giving up a valued good is greater than the utility gain associated with receiving it" (Tversky \& Khaneman, 1991, p. 1041). Thaler labeled this consequence of loss-aversion as the "endowment effect" (1980).

The argument made here is that an insurgency engaged in perilous combat with the state, would be willing to "pay more" (in casualties) even as winning was becoming increasingly less likely. This follows if it is true that "people tend to give more weight to the value of a potential outcome than to the likelihood of its occurrence" (Levy, 2003, p. 219). In assessing different insurgencies, it is not clear when this willingness to suffer future casualties would end.

\section{Collective Decision-making}

The potential shortcomings of prospect theory in aiding the analysis of group decision-making have received comment.

[A] limitation of prospect theory for the study of politics is that it is a theory of individual choice, while most of the questions we want to understand about politics involve the choices of collective decision-making bodies (such as states or organizations). The concepts of loss aversion and preference reversal, were based on evidence of individual decision-making, not group decision-making. In the absence of further empirical research we cannot automatically assume that these concepts [...] apply equally well at the collective level. (Levy, 2003, p. 233).

\subsection{Group Decisions}

Clearly the limitation of prospect theory noted in the above paragraph would apply to an analysis of an insurgency decision regarding whether or not to continue the resistance in the "risky" manner of mounting a metropolitan defense. Viewed by a neutral outsider, the defenses of Kilinochchi in Sri Lanka in 2008 and Grozny in Chechnya in 1999, would surely seem like "long shots", following the heavy losses (in both casualties and territory) both theLTTE (ICG, 2008, p. 5; Mehta, 2010, p. 17), and the Chechen resistance (BBC News, 1999; New York Times, 1999), had already incurred prior to mounting their respective urban defenses.

\subsection{Individual Motivation}

A question that seems important but is probably impossible to answer definitively, is whether the insurgent leadership in each case viewed the city defenses as gambles which, while striving for a "reversal of fortune" victory, ran the risk of a greater loss than would be incurred by simply abandoning the two sites and retreating to safer ground. In other words, the insurgent leadership in each case was "gambling by accepting a chance of a greater loss in return for a chance of no loss (or even a victory)..." (Jervis, 1992, p. 188). But at issue is what motivates individuals to participate in collective action in the form of joining an insurgency in the first place, and then (discounting for the moment the strong possibility of coercion by the insurgent leadership) join in the "against all odds" effort to defend a specific locality.

\subsection{Domain of Losses}

Fanis has posited that "what motivates individuals to participate in collective action [is] their desire to recoup recent losses..." (2004, p. 364). In general, she goes on to note that when people are in the domain of losses, "they will be risk-acceptant and choose the option that has a lower probability of occurring, even if it will yield higher loss if it does not occur, than the other option, which will yield a certain but smaller loss" (2004, p. 367). One could view an insurgency decision to "stand and fight" and winning, as having a low probability (but a large "payoff'), but fighting, and losing, the battle as having a greater loss than retreating, which would be a certain loss, but a smaller one (fewer casualties).

\subsection{Group Cohesion}

Because insurgencies, as paramilitary organizations, provide little room for discussion in terms of decision-making, it may be that insurgency risk-taking is derived largely from group cohesiveness generated by 
history (i.e., experience) and group composition.One way to grasp the idea of group cohesion is to understand it to mean that individuals in the group will support group decisions or actions of the group, even if particular individuals do not agree with the proposed decisions or actions. "Group identification in turn increases cooperation, as it leads individual group members to substitute group regard [in place of] egoism as the principle guiding their choices" (Bornstein, 2003, p. 138). Gross and Martin suggest that cohesiveness can be understood as the degree of resistance of a group to "disruptive forces", and then to ask how strong (or weak) a disruptive force would have to be in order for the group to begin disintegrating (1952, p. 553).

\section{Acquisition as Endowment}

\subsection{Time of Possession}

It is the degree of cohesion between group members, produced through significant past losses incurred by the group, which likely helps to drive agreater than might be expected risk propensity of the latter.The contention I make here is that the group cohesion exhibited by both insurgencies stems from when, and most importantly how, the two sites of Kilinochchi and Grozny had been "acquired". Kilinochchi had been captured from the SLA in 1998(DeVotta, 2009; Jeyaraj, 1999), and Grozny had been kept from Soviet capture in the First Russia-Chechen war in 1995 (Kneyzsw \& Sedlickas, 1999; Lapidus, 1998). This allowed the LTTE to claim Kilinochchi as "theirs", since they had held it for ten years prior to 2009, and similarly allowed the Chechen resistance to claim Grozny as "theirs", since they had possessed it for four years prior to 1999. In prospect theory terminology, the two insurgencies came to see their respective capitals as their "endowments".

\subsection{Subjective Value}

Thaler found that the process of acquiring a possession enhances its value (1980, p. 43-45). In fact such a possession can be "over-valued", particularly with the passage of time. Jervis noted that as the "time of possession" is extended, and the effort to maintain possession is considerable and sustained, the subjective value of the possession will increase (1989, pp. 168-690). Kahneman \& Tversky put it in "transaction" terms: [t]hat is, the highest price that an individual will pay to acquire an asset will be smaller than the minimal compensation that would induce the same individual to give up that asset once it is acquired" (emphasis added) (1984, p. 348).

\subsection{What Is at Risk}

In the case of the two insurgencies' behavior examined here, what was at risk by defending the two sites was exceedingly large; "everything" was at risk, or nearly so. That is, prior to the initiation of the two battles under study, choosing to fight rather than retreat greatly increased the risk of losing the war, suffering exceedingly high numbers of casualties from losing the battle. But making the decision to fight at the two battle sites, brought the possibility of turning the entire tide of the war, although even the possibility of winning meant incurring considerable casualties. The odds were long for this possibility of winning the war to occur, but the rewards were inestimable. The probable consequence for losing was well understood by both insurgencies before the respective battles began.

\subsection{Mode of Decision-making}

An observation regarding the individual versus group decision-decision making question can be placed here. That is, military and paramilitary (insurgencies) organizations by definition have "command" organizational structures. For the most part, there is little room for "discussion" in the decision-making process that occurs in these organizations (Stoner, 1968); certainly not beyond the top tier of officers. So to a substantial extent, decision-making in military and paramilitary organizations does not occur in a strictly collective manner, in the sense of decisions taken only after group discussion.Individual cadres in an insurgency could be seen as inherently risk-takers, otherwise they would not have joined an insurgency (Begum \& Ahmed, 1986). It should be kept in mind there would be some likelihood that coercion was the primary generator of insurgency membership in at least some cases.

\section{Insurgency Choice}

\subsection{Defending Possessions}

Both insurgent organizations, the Chechen rebels, and the LTTE, made their defensive stands encumbering great losses, at specific sites against superior forces in order to avoid the loss of their "possessions," of Grozny and Kilinochchi, respectively. My contention is that both insurgencies regarded the two battle locales, Kilinochchi and Grozny, as genuine defenses of what was theirs, not just attempts to hold onto recent gains. Choosing to mount these two defensive efforts was in each case a "risky choice," with a decidedly low probability of success.

"An insurgency is a risky and highly complex human activity susceptible to a range of mistakes by its 
protagonists" (Krause, 2009, p. 49). But in each case the insurgency leadership had determined that if the battle could be won, the entire tide of the civil war could be turned, albeit not a course of action without its own costs. Given my premise that prospect theory can hold for certain types of collectivities, the theory advises us to not be greatly surprised by these two decisions. This is so because of the finding that individuals (and certain groups) are willing to risk "more"; i.e., choose the course of action between at least two alternatives which will bring greater negative consequences (in the current context, losing the war), if the gamble (battle) is lost, than the other alternative of retreating and avoiding devastating casualties, particularly if what they risk is "theirs".

\subsection{Ownership}

Time of "control" of a locale that has been fought for provides a strong sense of ownership; the longer a piece of territory has remained under the military control of an insurgency, the stronger a sense of ownership prevails.In this instance of insurgencies that have gained control of territory only by incurring extensive casualties, it is not the mechanism of a "sunk costs bias" that also comes into play (Arkes \& Blumer, 1985). In economic decision-making theory, the belief is that only potential future costs should be taken into account when faced with a present decision choice, and not retrospective costs that have failed to produce or contribute to a positive outcome. Allowing past costs which have not paid "dividends" to have an impact on future decisions is irrational in traditional economic theory because those costs cannot be recovered (Steele, 1996, pp. 608-610). Believing those costs can be "recovered" or "justified" by future actions is regarded as a "fallacy" (Janis, 1972).

But part of my argument in this paper is that the Kilinochchi and Grozny cases can be more aptly explained as instances of an "impending-benefit bias" analysis on the part of the respective insurgencies, rather than examples of the sunk-cost bias or fallacy. I contend this is so because in the battles which allowed the LTTE to capture Kilinochchi in 1999, and the Chechen resistance to hold Grozny in 1995-96, the casualties incurred were costs which produced positive outcomes. These outcomes helped to cement a sense of endowment each insurgency could then claim.

\subsection{Choosing the Level of Risk}

The endowment effect in the case of insurgency decision-making is what makes risky decisions by insurgent groups more likely to be entered into, than not. Insurgencies will often be loss-aversive and risk acceptant, because the endowment effect (losses are more hurtful than gains are pleasurable) is an incentive for the group to be so. In the current two cases group cohesion is produced in large part through the endowment effect produced by the earlier victories at Kilinochchi and Grozny. Thus, the groups were "risk-acceptant" and "loss averse" insofar as taking a gamble (choosing to fight at the two sites), even though there was a smaller chance of victory and turning the tide of war, than of losing the battles (incurring sizeable casualties) and making more certain the entire war would be lost.

The insurgencies made this choice rather than choosing to retreat which, while engendering a certain but smaller loss of the metropolitan sites (incurring fewer casualties), would not bring about the loss of the war generally, or at least would not greatly increase the likelihood of the latter. Had the insurgencies made these latter choices they would have been exhibiting loss-acceptant and risk- aversive behavior. The insurgencies (particularly the leadership) in each case determined the former choices provided a high risk "chance" of retaining their respective endowments, an outcome which made the gambles worth taking.

\section{References}

Arkes, Hal R., \& Catherine Blumer. (1985). The psychology of sunk costs. Organizational Behavior and Human Decision Processes, 35, 124-140. http://dx.doi.org/10.1016/0749-5978(85)90049-4

BBC News. (1999, December 21). Fierce fighting around Grozny. Retrieved from http://news.bbc.co.uk/2/hi/europe/568612.stm

Begum, H. A., \& E. Ahmed. (1986). Individual risk taking and risky shift as a function of cooperation-competition proneness of subjects. Psychological Studies, 31, 21-25.

Blank, A. D. (1968). Effects of group and individual conditions on choice behavior. Journal of Personality and Social Psychology, 8, 294-298. http://dx.dot.org/10.1037/h0025596

Bornstein, Gary. (2003). Inter-group conflict: individual, group, and collective Interests. Personality and Social Psychology Review, 7(2), 129-145. http://dx.doi.org/10/1207/S15327957PSPR0702_129_145

Brown, R. W. (1965). Social psychology. New York, NY: Free Press.

Clark, Russell D. (1971). Group induced shift toward risk: a critical appraisal. Psychological Bulletin, 76(4), 251-270. http://dx.doi.org/10.1037/h0031567 
DeVotta, Nei. (2009). The Liberation Tigers of Tamil Eelam and the lost quest for separatism in Sri Lanka. Asian Survey ,49(6), 1021-1051. http://dx.doi.org/10.1525/as.2009.49.6.1021

Fanis, Maria. (2004). Collective action meets prospect theory: an application to coalition building in Chile. Political Psychology, 25(3), 363-388. http://dx.doi.org.10.1111/j.1467-9221.2004.00376.x

Gordon, Michael R. (1999, November 29). Russian promises escape route for civilians to flee Grozny, New York Times, (pp. 10). Retrieved from http://www.nytimes.com/1999/11/29/world/russia-promises-escape-route-for- civilians-to-flee-grozny.html

Gross, Neal \& William E. Martin. (1952). On group cohesiveness. American Journal of Sociology, 57(6), 546-564. http://dx.doi.org/10.1086/221041

Hariharan, R. (2008, December 10). Sri Lanka: the slow crawl to Kilinochchi - update No. 159, South Asia Analysis Group, 488. Retrieved from http://www.southasiaanalysis.org/\%5Cnotes5\%5Cnote $488 . \mathrm{html}$

International Crisis Group (ICG). (2008, February 20). Sri Lanka's return to war: limiting the damage. Asia Report, 146, 1-33. Retrieved fromhttp://www.crisisweb.org

Janis, I. (1972). Victims of groupthink. Boston, MA: Houghton-Mifflin.

Jervis, Robert. (1989). The meaning of the nuclear revolution. Ithaca, NY: Cornell University Press.

Jervis, Robert. (1992). Political implications of loss aversion. Political Psychology, 13(2), 187-204. http://dx.doi.org/10.2307.3791678

Jeyaraj, D. B. S. (1999). LTTE offensive. Frontline, 16(25). Retrieved from http://www.frontline.in/f11625/16250040.htm.

Kahneman, Daniel \& Amos Tversky. (1979). Prospect theory: an analysis of decision under risk. Econometrica, 47(2), 263-291. http://dx.doi.org/10.2307/1914185

Kahneman, Daniel \& Amos Tversky. (1983). Choices, values and frames. American Psychologist, 39(4), 341-450. http://dx.doi.org/10.1037/0003-066x.39.4.341/

Kneyzsw, Stays \& Romanas Sedlickas (1999). The war In Chechnya. College Station, TX: Texas A \& M University Press, 1999.

Lapidus, Gail. (1998). Contested sovereignty. International Security, 23(1), 5-49. http://dx.doi.org/10.2307/2539261

Levy, Jack (2003). Application of prospect theory to political science. Synthese, 135, 215-241. http://dx.doi.org/10.2307/2539261

Mehta, Ashok. (2010). Sri Lanka's ethnic conflict: how Elam IV was won. Manekshaw Paper, 22, Center for Land Warfare Studies, New Delhi,

New York Times. (1999, December 16). Russian tanks pounding Grozny from 3 directions. Retrieved from http://www.nytimes.com/1999/12/18/world/russian-tanks-pounding-grozny-from-3-directi

Oliker, Olga (2001). Russia's Chechen wars, 1994-2000. Santa Monica, CA: Rand Arroyo Center.

Stoner, J. A. F. (1968). Risky and cautious shifts in group decisions: the influence of widely held values. Journal of Experimental Social Psychology, 4, 442-459. http://dx.doi.org/10.1016/0022-1031(68)90069-3

Thaler, Richard. (1980). Toward a positive theory of consumer choice. Journal of Economic Behavior and Organization, 1, 39-60. http://dx.doi.org/10.1016/0167-2681(80)90051-7

Tversky, Amos \& Daniel Kahneman. (1992). Advances in prospect theory: cumulative representation of uncertainty. Journal of Risk and Uncertainty, 5, 297-323. http://dx.doi.org/10.1007/BF00122574

Tversky, Amos \& Daniel Khaneman. (1991). Loss aversion in riskless choice. The Quarterly Journal of Economics, 106(4), 1039-1061. http://dx.doi.org/10.2307/2937956

U.N. Secretary-General. (2011, March 31). Report of the U.N. Secretary-General. Retrieved from http://www.un.org/News/dh/infocus/Sri Lanka/POE_Report_Full.pdf. 